\title{
Başlık ve Noktalama: Akademik Makale Başlıkları Üzerine Art Zamanlı Bir Dil Bilim İncelemesi
}

\author{
Title and Punctuation: A Diachronic Linguistic Analysis on \\ Academic Article Titles
}

\section{Şahru Pilten Ufuk}

\section{$\ddot{O} z$}

Başlıklar bir akademik makalenin en çok okunan bölümüdür. Yayınların ulaşılabilirliğine/seçilebilirliğine olumlu ya da olumsuz etki yapma gücüne sahiptir. Bu özelliği akademik camiada başlıklara verilen önemi arttırmıştır. Nitekim 20. yüzyılın son çeyreğinden itibaren başlayan çalışmalarla Batı literatüründe başlıklarla ilgili muazzam bir literatür oluşturulmuştur. Öyle ki günümüzde "başlık bilim" olarak adlandırılan bir alandan söz edilmeye başlanmıştır. Bununla birlikte başlıklar Türk literatüründe fazla çalışılmış konulardan biri değildir.

Bu çalışmada 1937-2016 yılları arasında Türkiye Türkçesiyle yazılmış tarih alanındaki akademik makale başlıklarında noktalama işareti kullanımları derlem tabanlı, art zamanlı bir bakış açısıyla incelenmiştir. Bulgulardan hareketle akademik makalelerdeki noktalama işareti kullanımının bireysel bir tutum mu yoksa dönemsel bir eğilim mi olduğu sorgulanmış, dönemler arasındaki benzerlikler ve farklılıklar ortaya koyulmuştur.

Anahtar Kelimeler: Başlık, Noktalama, Akademik Makale Başlıkları, Tarih Konulu Akademik Makale Başlıkları, Dil Bilim, Başlık Bilimi

\footnotetext{
Yrd. Doç. Dr., Sakarya Üniversitesi, Fen Edebiyat Fakültesi, Türk Dili ve Edebiyat1 Bölümü Öğretim Üyesi, sahrupiltenufuk@sakarya.edu.tr

Bu makale iThenticate sistemi tarafından taranmıştır.

Makale Gönderim Tarihi: 20.01.2017
}

DOİ: 10.17550/akademikincelemeler.286737 


\begin{abstract}
Titles are the most read section of an academic article. They have the power to make a positive or negative effect on the availability / selectivity of publications. Those features have increased the importance given to the titles in academia. As a matter of fact, a vast literature on titles has been produced in Western literature with studies starting from the last quarter of the 20th century. So much so that nowadays a field called "titlelogy" has begun to be mentioned. However, the titles are not one of the more studied topics in Turkish literature.

In this study, the use of punctuation marks in academic article titles in the field of history written in Turkey Turkish between 1937-2016 has been investigated from a diachronic, corpus based point of view. From the findings it has been questioned whether the use of punctuation marks in academic titles is an individual attitude or a periodic tendency and similarities and differences of the periods are revealed
\end{abstract}

Keywords: Titles, Punctuation, Academic Article Titles, Titles of Academic Articles in History, Linguistics Titlelogy 


\section{Giriş}

Son on yıl içinde özellikle elektronik dergilerin yaygınlaşmasıyla yayınlanan akademik makale sayısında büyük bir artış yaşanmıştır. Nitekim 2015 y1lı itibariyle dünyada hakem incelemesinden geçmiş makale sayısı yıllık 1,5 milyona ulaşmıştır (Biswas ve Kirchherr, 2015). Makalelerin nicelik açısından çokluğu araştırmacıların ilgi duydukları alanlardaki bütün makaleleri okuyamamasına yol açmakta ve onları okuyacakları makaleler arasında hızlı bir seçim yapmak zorunda bırakmaktadır. Araştırmacıların arama motorlarının kendilerine önermiş olduğu binlerce yayın arasından eleme yapmak için kullandıkları temel seçim ölçütü makale başlıklarıdır. Okuyucunun makalenin içeriği hakkında fikir sahibi olması, makalenin araştırma konusuna uygun olup olmadığına veya makaleyi okuyup okumayacağına karar vermesi başlığa bağlı olarak meydana gelen süreçlerdir (Jamali ve Nikzad, 2011).

Yayınların ulaşılabilirliğine/seçilebilirliğine olumlu ya da olumsuz etki yapma gücü akademik camiada başlıklara verilen önemi arttırmıştır. Nitekim 20. yüzyılın son çeyreğinden itibaren başlayan çalışmalarla başlıklarla ilgili muazzam bir literatür oluşturulmuştur. Öyle ki günümüzde "başlık bilim" (İng. titlelogy) olarak adlandırılan bir alandan söz edilmeye başlanmıştır (bkz. Biacchi, 2003, Gesuato, 2008, Soler, 2011). Başlıklarla ilgili çalışmalar tek disiplin üzerine odaklananlar (bkz. Whissell, 1999; Goodman vd., 2001; Biacchi, 2003; Forray ve Woodilla, 2005; Wang ve Bai, 2007; Gesuato, 2008), disiplinler arası çalışmalar (bkz. Buxton ve Meadows, 1977; Dillon, 1982; Yitzhaki, 1994; Fortanet vd., 1997, 1998; Anthony, 2001; Haggan, 2004), kültürler arası çalışmalar (bkz. Nord, 1995; Busch-Lauer, 2000, Soler, 2011), dönemler arası çalışmalar (bkz. Rosner, 1990; Salager-Meyer ve Alcaraz Ariza, 2013) şeklinde sınıflandırılabilir.

Başlıklarla ilgili akademik yayınlarda özellikle dolaylamalar, kelime yoğunluğu (İng. lexical density), anlam şifrelemesi (İng. semantic encoding), noktalama işaretlerinin kullanımı, uzunluk, kelime seçimleri, söz dizim ve dil bilgisi yapısı gibi konular incelenmiştir. $\mathrm{Bu}$ unsurların makalenin atıf alma oranına etkisi üzerinde duran yayınların sayısı da son dönemlerde artmıştır (bkz. Sagi ve Yechiam, 2008; Stremersch vd., 2007; Jacques ve Sebire, 2009; Moore, 2010; 
Butter ve van Raan, 2011; Jamali ve Nikazad, 2011; Habibzadeh ve Yadollahie, 2012).

Başlıklar Türk literatüründe fazla çalışılmış konulardan biri değildir. Bu konuda yapılmış olan çalışmalar metin yazım kuralları genelinde değerlendirilebilir. Bu çalışmada 1937-2016 yılları arasında Türkiye Türkçesiyle yazılmış tarih alanındaki akademik makale başlıklarında noktalama işareti kullanımları derlem tabanlı, art zamanlı bir bakış açısıyla incelenmiştir. Bu bağlamda belirlenen örneklemdeki noktalama kullanımları belirlenmiştir. Bulgulardan hareketle noktalama işareti kullanımının bireysel bir tutum mu yoksa dönemsel bir eğilim mi olduğu sorgulanmış, dönemler arasındaki tutum benzerlikleri ve farklılıkları ortaya koyulmuştur.

\subsection{Akademik makale başlıklarında noktalama işareti kullanımı üzerine çalışmalar}

Akademik başlıklarda yer alan noktalama işaretleriyle ilgili araştırmalarda büyük ölçüde iki nokta işaretinin kullanımına odaklanılmıştır. Dillon (1981, 1982), Michelson (1994) ve Hartley (2007a, 2007b)'in noktalama işaretleri arasında iki nokta işaretinin baskın olarak kullanıldığını belirledikleri çalışmaları bu sınıfa dâhil edilebilir.

Dillon (1981) akademik dergilerde yer alan 804 makale başlığında iki nokta kullanımını incelemiş ve kullanım oranının teorik araştırma dergilerinde (\%34), deneysel araştırma dergilerinde (\%18) ve pedagojik dergilerde (\%10) olduğunu tespit etmiştir. Ayrıca Dillon (1981) iki noktanın basılmamış çalışmalara oranla basılmış makalelerde daha çok yer aldığını belirlemiştir. Dillon (1982) bu alandaki bir diğer çalışmasında ise 1880-1980 yılları arasında eğitim, psikoloji ve edebiyat eleştirisi alanlarında yayınlanmış 1.150 araştırma makalesi başlığını incelemiş ve iki nokta işaretinin bu üç alanda da istikrarlı yükselişini fark etmiştir.

Michelson (1994) endüstri ilişkileri üzerine 2000'in üzerinde akademik başlık inceleyerek bunlardan \%38'inin iki nokta ihtiva ettiğini ve iki noktanın varlığının dergilerin yaşıyla ters orantılı olduğunu belirlemiştir. 
Fortanet vd. (1997) bilgisayar bilimleri, uygulamalı dil bilim, kimya, iş ve ekonomi üzerine 200 araştırma makalesini yapı ve içerik açısından incelediği çalışmasında iki nokta, noktalı virgül ve noktanın iş ve ekonomi başlıklarında en sık kullanılan noktalama işaretleriyken bilgisayar bilimleri başlıklarında en az kullanılanlardan olduğunu bildirmiştir.

Akademik başlıklarda yer alan noktalama işaretleri üzerine yapılan çalışmalarda Anthony (2001)'nin araştırması kendisinden sonrakilere öncü olması açısından ayrı bir önem taşır. Anthony (2001) çalışmasında çeşitli bilgisayar bilimi alt disiplinine ait 600 başlığı noktalama kullanımları da dâhil olmak üzere farklı açılardan ele almıştır. Bu bağlamda iki nokta, noktalı virgül, kısa çizgi ve nokta olmak üzere beş noktalama işareti kullanımını incelemiş̧ir. Sonuç olarak bu noktalama işaretlerinin ortak noktasının çok birimli başlıkları farklı bölümlere ayırmak olduğunu belirlemiştir. Ayrıca iki noktanın bütün araştırma başlığı türlerinde var olduğunu ve birleşik başlıkları iki bölüme ayırmak için kullanıldığını ortaya koymuştur.

Sonraki çalışmalardan Lewinson ve Hartley (2005) iki noktalı başlıkların bu işaretin bulunmadığı başlıklara oranla daha uzun ve daha bilgilendirici olduğunu belirlemiştir. Hartley (2007a, 2007b) başlıklarda iki nokta kullanımında farklı disiplinlerde farklı tutumlar olduğunu, sanat alanında bilim alanındakinden çok daha fazla kullanıldığını ortaya koymuştur.

Literatürde başlıklarda iki nokta işaretinin kullanılmasının avantajları ile ilgili tartışmalar da yapılmıştır. Bu tip başlıkların çok sayıda anahtar kelime içerdiği için makaleyi veri tabanlarında daha bulunabilir ve görülebilir hâle getirdikleri savunulmuştur (bkz. Moore, 2010). Bununla birlikte iki nokta işareti içeren başlıkların atıf alma oranıyla ilgili yapılan çalışmalar bu görüşü çürütmüştür (bkz. Hartley, 2007a, 2007b).

$\mathrm{Bu}$ konuda söz edilmesi gereken bir başka araştırma da Ball (2009)'ın fizik, yaşam bilimleri ve eczacılık alanında 1966-2005 yılları arasında Scopus'ta yer alan 20 milyon bilimsel makaleyi incelediği geniş ölçekli çalışmasıdır. Ball (2009) araştırma sonucunda son 40 yıl içinde soru işareti kullanılan başlıklarda \%50-\%200'den fazla 
artış olduğunu belirlemiştir. Bilimsel makalelerde artan soru işaretli başlıklarının arkasındaki belirleyici faktörlerden birinin de "pazarlama boyutu" olduğundan söz etmiştir.

Başlıklarda noktalama işaretinin kullanımıyla ilgili çalışmalarda ortaya konan en önemli bulgulardan birisi de noktalama işaretleri ile başlıklarda yer alan bilgi birimi sayısı arasındaki olumlu ilişkidir. Bilgi birimleri (İng. information units) yeni bilginin kodlandığ 1 ünitelerdir. Bazı başlıklar tek bir bilgi biriminden meydana gelirlerken bazıları birden fazla bilgi biriminden oluşabilir. Gesuato (2008: 137) bilgi birimlerin varlığı ve sayısının noktalama işaretlerinin kullanımıyla belirleneceğini ortaya koymuştur. Ona göre nokta, iki nokta, noktalı virgül, soru işareti veya kısa çizgi kuvvetli bir iç durak oluştururken virgüller veya parantezler ise başlıktaki iç sınırlamaların belirticisidir. Başlıklarda metin düzenlemesini (İng. textual organization) yani bilginin metinde yapılandırılmasını tanımlayabilmek için başlıkların bilgi birimlerinin incelenmesi gereklidir.

\section{2. İnceleme}

\subsection{Yöntem ve Sinurlılıklar}

$\mathrm{Bu}$ çalışmada derlem tabanlı, art zamanlı bir inceleme yöntemi kullanılmıştır. Araştırılacak akademik başlıklarının kapsamı sosyal bilimler alanıyla sınırlandırılmıştır. Başııklar aşağıda verilen araştırma soruları dâhilinde incelenerek gruplandırılmıştır.

Akademik başlıkların düzenlemesinde:

(i) Noktalama işaretlerinden ne oranda yararlanılmıştır?

(ii) Hangi noktalama işaretlerinden yararlanılmıştır?

(iii) Kullanılan noktalama işareti türleri yıllar içinde anlamlı bir değişim göstermekte midir?

(iv) Noktalama işaretinden yararlanma oranları yıllar içinde anlamlı bir değişim göstermekte midir?

(v) Noktalama işareti kullanımı konusunda var olan belirli yıllara özgü üslup özelliklerinden söz edilebilir mi?

Derlemde geçmiş yıllar arasında karşılaştırma yapılmasına olanak 
sağlamak amacıyla farklı yıllara ait makale başlıkları farklı dönemleri temsil eden üç alt derlem altında sınıflandırılmıştır. Birinci derlem 1937-1942, ikinci derlem 1960-1965; üçüncü derlem 1985-1990 yılları arası dördüncü derlem ise 2011-2016 y1lları arasında sosyal bilimlerde kullanılan akademik makale başlıklarını içine almaktadır. Her üç alt derlem için de Türk Tarih Kurumu tarafından yayınlanan Belleten dergisi kullanılmıştır. Alt derlemlerde yer alan makale sayılarında düzenlenme yapılarak söz konusu yıllar arasında yayınlanan Türkçe yayınlanmış makale başlıklardan rastgele seçilen 133 tanesi derleme dâhil edilmiştir. Tablo 1'de derlemde yer alan başlıkların alınmış olduğu dergilerin künye bilgileri yer almaktadır:

Tablo 1: Alt derlemde kullanılan makalelerin TTK Belleten Dergisi künye bilgileri

\begin{tabular}{|c|c|c|c|c|}
\hline Yillar & $1937-1942$ & $1960-1965$ & $1985-1990$ & $2011-2016$ \\
\hline Cilt & I-VI & XXIV-XXIX & XLIX-LIV & LXXV-LXXX \\
\hline Say1 & $1-23,24$ & $93-116$ & $193-211$ & $272-288$ \\
\hline
\end{tabular}

Bu çalışmada oluşturulan derlemde Belleten dergisinin örneklem olarak seçiminin başlıca sebepleri:

(i) Türkiye Cumhuriyeti'nin en eski akademik dergilerinden birisi olmas1,

(ii) Latin alfabesiyle yayınlanan ilk tarih dergisi olma özelliğini taş1mas1,

(iii) 1937 'den itibaren kesintisiz yayınlanmas1,

(iv) 1963 'ten itibaren uluslararası alan indekslerince taranıyor olması gibi özellikleriyle art zamanlı incelemeler için uygun olmasıdır.

Ayrica

(i) Geçmişten itibaren dizinlenmeye devam ettiği diğer alan indekslerinin yanı sıra 2010 yılından itibaren Arts and Humanities Citation Index (AHCI) tarafından da dizinlenmeye başlamıştır. Akademik camiada prestij sahibi dergilerden olma özelliğini günümüzde de koruması bu dergiyi eş zamanlı incelemeler için uygun kılmaktadır. 
Derlemdeki başlıklar sadece Türkiye Türkçesi ile sınırlandırılmıştır. Yabancı dilde yazılmış makalelerin Türkçe karşılıkları dergi içinde verilmediği için bu başlıklar derleme alınmamıştır. Ayrıca kitap tanıtımları da makale başlıklarının içine dâhil edilmemiştir.

\subsection{Bulgular}

Yapılan incelemede noktalama kullanımı sayısının en düşük olduğu dönemin 1937-1942 yılları arasında olduğu görülmüsstür. Bu yıllar arasında her yüz başlıktan sadece 31 'inde noktalama kullanılmıştır. 1960 'tan itibaren bu oranın artış gösterdiği tespit edilmiştir. Bununla birlikte 1960-2016 yılları arasında başlıklarda noktalama işareti kullanma tutumunda bir tutarlılık görülmemiştir. Bu yıllar arasında noktalama kullanım oranı ortalaması \% 74'tür. Kullanılan noktalama işareti türlerinde ve makale başı düşen ortalama noktalama işareti sayısında ise dönemler arasında belirgin bir artış gözlemlenmiştir. Araştırma istatistikleri Tablo 7'de verilmiştir:

Tablo 2: Başlıklarda noktalama işareti kullanım oranları

\begin{tabular}{|l|l|l|l|l|}
\hline Yıllar & $1937-1942$ & $1960-1965$ & $1985-1990$ & $2011-2016$ \\
\hline $\begin{array}{l}\text { Makale Başı Düşen } \\
\text { Ortalama Noktalama } \\
\text { İşareti Sayısı }\end{array}$ & 0,44 & 1,41 & 1,22 & 2,18 \\
\hline $\begin{array}{l}\text { Kullanılan noktalama } \\
\text { işareti türleri }\end{array}$ & 7 & 7 & 9 & 10 \\
\hline $\begin{array}{l}\text { Noktalama kullanılan } \\
\text { başlık sayısı }\end{array}$ & $41(\% 31)$ & $105(\% 79)$ & $74(\% 56)$ & $116(\% 87)$ \\
\hline $\begin{array}{l}\text { Noktalama kullanılmayan } \\
\text { başlık sayısı }\end{array}$ & $92(\% 69)$ & $28(21 \%)$ & $59(\% 44)$ & $17(\% 13)$ \\
\hline
\end{tabular}

Başlıklarda en sık kullanılan noktalama işareti kesme işaretidir. Kullanım açısında ikinci sırada kısa çizgi, üçüncü sırada ise nokta yer almaktadır. En az kullanılan noktalama işareti ise eşitlik işaretidir. Sadece tek bir başlıkta eşitlik işareti kullanımına rastlanmıştır. Kullanılan noktalama işareti türleri yıllara göre artış göstermiştir. Eğik çizgi 1937-1965 aralığında kullanılmamıştır. Eşitlik işareti sadece 1985-1990; tırnak, tek tırnak işaretleri ise sadece 2011-2016 yılları arasında kullanılmıştır. Tablo 3 'te noktalama işaretinin yıllara göre kullanım bilgisi verilmiştir: 
Tablo 3: Başlıklarda Noktalama İşareti Kullanımı

\begin{tabular}{|l|l|l|l|l|l|}
\cline { 2 - 6 } \multicolumn{1}{c|}{} & \multicolumn{1}{l}{ Yllar } \\
\hline Noktalama İşaretleri & $\mathbf{1 9 3 7 - 1 9 4 2}$ & $\mathbf{1 9 6 0 - 1 9 6 5}$ & $\mathbf{1 9 8 5 - 1 9 9 0}$ & $\mathbf{2 0 1 1 - 2 0 1 6}$ & Toplam \\
\hline Kesme & $28(\% 47)$ & $103(\% 55)$ & $42(\% 26)$ & $89(\% 31)$ & 262 \\
\hline Kısa çizgi & $9(\% 15)$ & $34(\% 18)$ & $32(\% 20)$ & $62(\% 21)$ & 137 \\
\hline Nokta & $12(\% 20)$ & $27(\% 14)$ & $39(\% 24)$ & $39(\% 13)$ & 117 \\
\hline Virgül & $7(\% 12)$ & $13(\% 7)$ & $24(\% 15)$ & $20(\% 7)$ & 64 \\
\hline Yay Ayraç & $1(\% 2)$ & $7(\% 4)$ & $17(\% 10)$ & $32(\% 11)$ & 57 \\
\hline İki nokta & $1(\% 2)$ & $1(\% 0)$ & $5(\% 3)$ & $41(\% 14)$ & 48 \\
\hline Soru & $1(\% 2)$ & $3(\% 2)$ & $1(\% 0)$ & $3(\% 1)$ & 8 \\
\hline Ĕgik çizgi & - & - & $2(\% 1)$ & $2(\% 1)$ & 4 \\
\hline Eşitlik & - & - & $1(\% 1)$ & - & 1 \\
\hline Tirnak & - & - & - & $2(\% 1)$ & 2 \\
\hline Tek Tırnak & - & - & - & $1(\% 0)$ & 1 \\
\hline Toplam & 59 & 188 & 163 & 291 & 701 \\
\hline
\end{tabular}

\section{Bulguların Yorumlanması}

\subsection{Kesme İşareti}

Kesme işareti akademik başlıklarda genel olarak en çok kullanılan noktalamadır. Bununla birlikte kesme işaretinin dönemler arasındaki kullanım oranı farklılık göstermektedir. 1937-1965 arası kullanım oranı ortalama \%48'ken 1985-2016 arasında yüzde otuzun altına düşmüştür. 1960-1965 yıllarında 103 kullanımla bu işaretin en çok kullanıldığı dönemdir.

Kesme işaretinin sıkça kullanımı akademik makalelerde özel isimlere yer verilme oranının yüksekliğini, incelenen makalelerin kişiler, yerler, kurumlar veya eser adları üzerine yazıldığının göstergesidir. Nitekim sadece 3 kullanımda tarihlerden sonra gelen ekleri ayırmak için kullanılmıştır.

\subsection{Kısa çizgi}

Kısa çizgi kullanım oranı 1985-1990 yılları arasında hafif bir düşüş eğilimi gösterse de yıllar içinde genel olarak bir artış içindedir. 19371942 yılları arasında 9 kez kullanılan kısa çizgiye 2011-2016 yılları arasında 62 kez yer verilmiştir. Derlemde yer alan örneklerde 19371942 yılları arasında aşağıda sıralanan amaçlar için kullanıldığı tespit edilmiştir: 
İki ayrı soyadının birlikte kullanımlarında bu adları ayırmak için:

Bibliyografya, Stanley Lane - Poole

İki ırk ve devlet adı arasındaki bağı belirtmek için:

Türk-Osmanlı Tarihinin Karakteristik Noktalarına Bir Bakış

İki ırk ve din adı arasındaki bağı belirtmek için:

Türk-İslâm Devri Kitabe Estampajlart

Aynı kelimenin farklı dillerdeki karşılıkları arasındaki bağı belirtmek için:

Roma-Rum Kelimeleri

İki tarih arasında ila anlamı vermek için:

Muahhar Han Devrinde (M.S. 25-M.S220) Hun Tarihine Kronolojik Bir Bakış

1960-1965 arasında yukarıda belirtilenle kısa çizgi kullanımlarından sadece sonuncusu tespit edilmiştir. Bu dönemde kısa çizgi aşağıda belirtilen amaçlar doğrultusunda kullanılmıştır.

İki devlet arasındaki bağı belirtmek için:

1877-1878 Osmanll-Rus Harbinin Sebepleri

İki millet arasındaki bağı belirtmek için:

II. Dünya Savaşında Türk-Alman Ticaretindeki İktisadi Siyaset

Yer adları arasındaki bağı belirtmek için:

Bodrum-Dirmil Kazlsı Iskeletleri

Özel kişi veya yer adlarda yer alan kalıplaşmış kullanımlarda:

A ̆gaç-Eriler

Hasan-Âli Yücel

Kül-Tegin Anıtında 1958'de Yapılan Arkeoloji Araştırmalarının Sonuçları

Alaca-Höyük Çanak-Çömlekleri Üzerindeki Işaret ve Damgalar Ikilemelerde:

Alaca-Höyük Çanak-Çömlekleri Üzerindeki İsaret ve Damgalar

Arapça veya Farsça tamlamalarda 
Elfevaid-ül muadde li Nizam-i Hükûmet-i Bender-i Cidde

Yön isimlerinde:

Güney-Batı Anadolu'da Bulunan Erken Bronz Çağına Ait Mermer Ídol'ler

1985-1990 y1lları arasında daha önceki yıllarda tespit edilen kısa çizgi kullanım amaçlarından sadece iki devlet, iki millet, iki tarih arasındaki ilişkileri belirtmek için ve Arapça ve Farsça tamlamalarda kullanılmıştır. Farklı kullanım amaçları aşağıda sıralanmıştır:

İki kişi arasındaki bağı belirtmek için:

İngiliz Belgelerine Göre Mustafa Kemal-Lawrence Görüşmesi

İki din arasındaki bağı belirtmek için:

Hz. Muhammed Devrinde İslâm-Hiristiyan Münasebetlerine Toplu Bir Baklş

İki dil ismi arasındaki bağı belirtmek için:

Taş Aletlerin Teknik Betimleri İçin Türkçe-Fransızca Bir Sözlükçük Denemesi İki kavram arasındaki bă̆ belirtmek için:

XVI. YY. da Osmanlı İmparatorluğunda Su-Yolculuk

İki bilim dalı arasındaki bağı belirtmek için:

Tokatta Ailenin Sosyo-Ekonomik Yaplsı (1771-1810)

2011-2016 yılları arasında daha önceki yıllarda tespit edilen kısa çizgi kullanım amaçlarından sadece iki devlet, kavram, millet, tarih, yer, bilim dalı arasındaki ilişkiyi belirtmek için, kalıplaşmış özel adlarda, Arapça ve Farsça tamlamalarda ve ikilemelerde kullanılmıştır. Farklı kullanım amaçları aşağıda sıralanmıştır:

Yer ve yön adları arasındaki bağı belirtmek için:

Diyarbakır'da Osmanlı Dönemi Şehir-İçi Hanları Üzerine Değerlendirme

Makalenin tezini ifade etmek için iki kavram arasında denklik kurmak amaciyla:

Balkan Savaşı - Kitlesel Ölüm ve Etnik Temizlik 
Makalenin kapsamını ifade eden ara sözü belirtmek için:

Polonezköy (Adampol) (1842-1922) - Kuruluş, Tabiyet Meselesi, Imar Faaliyetleri ve Sosyal Hayat -

\subsection{Nokta}

Ekonomi alanındaki makale başlıkları üzerine yaptığı çalışmada Fortanet vd. (1997) noktanın üç ana noktalama işaretinden biri olduğunu vurgulamıştır. Nitekim bizim çalışmamızda da genel toplamda nokta, sık kullanılan noktalama işaretleri içinde ilk üçe girmektedir. Nokta işaretinin makale başlıklarında kullanım sayısı 1985-1990 yıllarına kadar artı̧̧ göstermekle birlikte bu süreden sonra duraklama göstermiştir. 1937-1942 aralığında 12 nokta kullanımı tespit edilirken bu sayı 2011-2016'da 39'a çıkmıştır. Bütün alt derlemlerde aynı üç amaç için kullanılmıştır. Nokta işaretinin kullanım yerleri aşağıdaki şekilde siralanabilir:

1. Sayllardan sonra, sıra bildiren -IncI eki yerine:

XVI. Asırda Dini ve Sosyal Bir Inkılap Teşebbüsü

Selim III. ün Veliaht İken Fransa Kralı Lui XVI ile Muharebeleri

2. Kalıplaşmış kısaltmalarda:

Muahhar Han Devrinde (M.S. 25-M.S220) Hun Tarihine Kronolojik Bir Bakış

Hollandalı Bir Seyyah'ın 18. yy. Başında Doğu Kafkasya'da Gördüğ̈̈ Bazı Türk Eserleri

Anadolu'da Bulunan M.Ö. İkinci Bin Yllina Ait Alttndan Yüz Maskesi Profesör Dr. Gotthard Jaschke

Hz. Muhammed Devrinde İslâm-Hiristiyan Münasebetlerine Toplu Bir Bakış Kanuni Sultan Süleyman'in Boğdan Seferi ve Zaferi (1538 M. =945 H.) Cezzâr Ahmed Paşa (Ö. 1804) Hakkında Bir Takrîr Münasebetiyle Suriye'de Iktidar Oyunlart

Sayın Cumhurbaşkanı Org. Cemal Gürsel'in TTK'yı Ziyaretleri

3. İsim Kısaltmalarında kullanılmıştır: 


\section{TH. Makridi'nin Hatırasina}

Kavalalı M. Ali Paşa İsyanı Esnasında

N. Kemal'in Osmanlı Tarihine Dair

Kurtuluş Savaşı Günlerinde M. Kemal-Enver Çatışması

Türk-Sovyet Illişkilerinde G.V. Çiçerin ve Ermeni Meselesi

\subsection{Virgül}

1960-1965 yıllarına kadar yükseliş göstermekle birlikte virgül kullanımı bu dönemden sonra belirli ölçüde azalmıştır. 1937-1942 arasında iki tip kullanımı gözlenmiştir:

Bildirim başlıklarında birbiri ardınca sıralanan eş görevli kelime ve kelime gruplarının arasında:

Atatürk Yaptıkları İle de, Anlattıkları ile de Büyüktür

Atatürk, Türk Milletinin Kalbinde, Türk Milletinin Ruhunda, Kendine Güvenme Kudretini Yarattı

Kendisiyle ilgili açıklama verilecek ifadeden sonra yer verilerek iki nokta işlevinde:

\section{Bibliyografya, Stanley Lane - Poole}

Daha sonraki yıllarda virgül yukarıda söz edilen amaçlarda kullanılmamıştır. 1960-2016 yılları arasında virgülün 6 farklı kullanımı belirlenmiştir. Bu kullanımlar aşağıda sıralanmıştır:

Birbiri ardınca sıralanan eş görevli kelime ve kelime grupları ayırmak amaciyla:

Konya, Karaman ve Civarl, Akhisar, Manisa, Izmir, Aydın ve Edirne'de Tetkiklerimiz Esas Noktaları Üzerine Bir Gezi Raporu

TTK Adına 1964 Yılında, Alaca-Höyük'te Yapılan Kazıda Çıkarılan İki Eski Bronz Çă̆l İskeletinin Incelenmesi

Bir kelimenin kendisinden sonra gelen kelime veya kelime gruplarıyla yapı ve anlam bakımından bağlantısı olmadığını göstermek ve anlam karışıklı̆̆ını önlemek amacıyla:

Barak Reis'in, Şehzade Cem Mes'elesiyle Ilgili Olarak 
Savoie'ya Gönderilmesi

Orhan Gazi'nin, Vefat Eden Oğlu Süleyman Paşa İçin Tertip Ettirdiği Vakfiyenin Aslı

Makalede incelenen alt konu başlıklarının sıralanması amacıyla:

Ahmed Vefik Paşa'nın Şahsiyetinin Teşekkülü, Hususî Hayatı ve Muhtelif Karakterleri

Makalenin genel ve özel kapsamını belirtmek amacıyla:

Bilgi Yöntemi, Özellikle Tarih Yönetimi Üzerine Kısa Notlar

Makalede incelenecek dönemi belirtmek amaciyla:

Tanzimat'ın Illanı Stralarında Türkiye'de Yönetim, 1826-1839

Makalenin bakış açısını belirtmek amacıyla:

XVI. Yüzyılda Sosyal, Ekonomik ve Demografik Bakımdan Balkanlarda Bazı Osmanlı Şehirleri

\subsection{Yay Ayraç}

Yay ayraç kullanımı yılları arasında sürekli artmıştır. Kullanım oranı \%1'den \% 11'e yükselmiştir. Yay ayraç cümledeki anlamı tamamlayan ve cümlenin dışında kalan ek bilgiler için kullanılan bir noktalama işaretidir. Derlemdeki kullanım örnekleri de bu genel tanıma uymaktadır.

Yay ayraçlar 1937-1942 yılları arasında yer aldığı tek örnekte başlıkta belirtilen dönemin yaşanmış olduğu tarihsel aralı̆̆ açıklamak için kullanılmıştır:

Muahhar Han Devrinde (M.S. 25-M.S220) Hun Tarihine Kronolojik Bir Bakış

1960-1965 yılları arasında ise yukarıdaki kullanım dışında aşağıda sıralanan amaçlar doğrultusunda kullanılmıştır:

Aynı varlığına verilen farklı isimlendirmeleri açıklamak için:

Altıntepe (Urartu) İskeletlerine Ait Kalıntıların Tetkiki

Kişilerin doğum ve ölüm tarihlerini belirtmek için: 
Faik Reşit Unat (1899-1964) ve Bibliyografyast

Yer isimlerinin eski adlarını ifade etmek için:

İzmir Yakınında Kemal Paşa (Nif) da Laskaris 'ler Sarayı

Yapılan bir etkinliğinveya olayın tarihsel aralığının açıklanması için:

Tilmen Höyük Çalışmaları (1958-1960)

1985-1990 aralığında yay ayraç yukarıda sıralanan amaçlardan yalnızca kişilerin doğum ve ölüm tarihlerini belirtmek için kullanılmamıştır. Bununla birlikte kullanım oranının artmasıyla birlikte kullanım çeşitliliği de artmıştır. Bu dönemde belirlenen farklı kullanımlar aşağıda listelenmiştir:

Başlıkta verilen lakapta kastedilen kişiyi açıklamak:

Gazi'nin (Atatürk'ün) Halkçıllk Ülküsü, Halkevleri ve Sonrası

Başlıkta söze edilen kişinin lakabını belirtmek:

Türkiye Selçuklu Sultanı Siyavuş (Cimri)'un Sikkeleri

Alıntı terimlerin Türkçe karşılıklarını vermek:

Genç Bizans Devrinde Trepanasyon (Kafatası Delgi Ameliyatı)

Makale incelemesinin kapsadığı tarih aralıklarını belirtmek:

Memleketimizde Gençler İçin Kurulan Illk Dernekler, Gazete ve Gergiler (1913-1920)

Makale incelemesinin kapsadığı dönemleri belirtmek:

Orta Asya Mahalli Türk Hükümdar ve Aristokratlart arasında Islamiyet: Illk Müslüman Türk Hükümdarları (Emeviler Devri)

İncelenen eserin ilim dünyasındaki yaygın künyesini belirtmek:

Ashella Rituali (CTH 394) ve Hititlerde Salgin Hastalıklara Karşı Yapılan Majik İslemlere Toplu Bir Bakış

Yay ayracın en sık kullanıldığı dönem olan 2011-2016 aralığında yukarıda sayılan özelliklerden yalnızca başlıkta verilen lakapta kastedilen kişiyi açıklamak ve incelenen eserin künyesini belirtmek işlev- 
lerinde kullanılmamıştır. En çok incelenen konunun tarih aralıklarını belirtmek için kullanılmıştır. Farklı kullanımlar aşağıda sıralanmıştır:

Başlıkta günümüz Türkçesiyle verilen konu veya kavramın incelenen dönemdeki karşı1ıklarını belirtmek:

Halk Hekimliğinden Diş Hekimliğine: 19. Yüzyılda Osmanlı Devletinde Diş̧̧ilik Mesleği (Erbâb-ı Esnân)

Başlıkta söz konusu edilen olayın kesin tarihini belirtmek

Selanik Vilayeti Almanya ve Fransa Konsoloslarının Öldürülmesi Olayı (6 Mayıs 1876)

Sonradan alınan soyadlarını açıklamak:

İsmail (Tuncu) Bey'in Hâttra-i Seyahât'inde Sultan Reşad'in Rumeli Ziyareti Kosova

Makalenin yöntemini belirtmek:

Ortaçă̆ İslâm Kaynaklarında Tuna Bulgarları İçin Kullanılmış Olan Etnonimler (Kronolojik Bir Değerlendirme)

Makalede kullanılan kaynakları belirtmek:

1916 ile 1919 Yılları Arasında Krakov Müstahkem Mevkii Hastanelerinde Osmanlı Askerleri (Polonya Kaynakları Işı̆̆ı̆nda)

Şehir isimlerinin bağlı olduğu yer adlarını belirtmek:

XVII. ve XVIII. Yüzyıllarda Resmo (Girit) Manastır Vakıflarl

Başlıkta kullanılan çeviri kavramların orijinal dildeki karşılıklarını belirtmek:

Stratford Canning'in Raporlarina Göre Sultan Abdülmecid ve Ona Ingiltere Tarafindan Verilen Dizbă̆ Nişanı (Knight of the Garter)

Soru işaretiyle birlikte başlikta belirtilen bilginin şüpheyle karşılandığını veya kesin olmadığını göstermek için:

Tigunānu'dan (?) Arpa Hisseleri Hakkında Bir Tablet

3.6. İki nokta:

İki nokta işareti 1937-1942 ve 1960-1965 y1lları arasında 1'er kez kullanılmıştır. kullanımı 2011-2016 yıllarından önce ortalama \% 
2'ken bu yıllar arasında büyük bir artış göstererek \%14'e yükselmiştir. Bu yükselişe paralel olarak daha önceki dönemde kullanılan noktalama işaretleri arasında son sıralarda iken 2011-2016 yılları arasında kullanım sıklığı açısından 3. sıraya çıkmıştır.

Son dönemlerde iki noktanın başlıklardaki kullanma oranındaki artış sadece bizim dilimizde değil bütün dünyada görülmektedir (bkz. Dillon, 1982, Hartley, 2007 ve Michelson, 1994). İki noktanın kullanım oranındaki bu artış araştırmacıların dikkatini çekmiş ve pek çok yayında bu konuya yer verilmiştir. İki noktanın birleşik başlıkları iki bölüme ayırmak için kullanılır (Antony, 2001). İki noktanın kullanıldığı başlıklara iki nokta başlıkları (İng. colonic titles), seri başlıklar (İng. series titles) veya birleşik başl1klar (İng. compound titles) adıverilir (Cheng vd., 2012). Birinci bölümde "isim" veya "konu" üzerinde durulurken ikinci bölümde "tanım", "kapsam", "metot" üzerine odaklanıldığı ifade edilmiştir (Antony, 2001). Literatürde iki nokta kullanılan başlıklar 5 ila 11 ayrı kategori içinde ele alınmıştır (Antony, 2001; Cheng vd., 2012). Bu çalışmada ise incelenen alt derlemlerde iki nokta kullanılan başlıkların toplam farklı 12 çeşidi tespit edilmiştir.

1937-1942 yılları arasında iki nokta tanım-konu arasında ilişki kurmak için kullanılmıştır:

Son Kapitülâsyonlardan Biri: Karantina Türkiye Tarihinin son XX Ylllik Devrine Ait Kronoloji

1960-1965 yıllarında ise tanım-isim şeklinde bir kullanım söz konusudur:

Isslz bir Adacı̆̆ın Koynunda Uyuyan Antitek Şehir: Kedreai

1985-1990 yıllarında her iki kullanım da tanıklanmıştır farklı bir kullanıma rastlanılmamıştır. 2011-2016 yılları arasında ise iki noktanın kullanım sıklığıyla birlikte kullanım çeşitliliği de artış göstermiştir. Aşağıda bu kullanımlar listelenmiştir:

1. Tanım-konu:

Bir Sosyal Sorumluluk Projesi: Tuna Vilayeti Islahhaneleri

Halk Hekimliğinden Diş Hekimliğine: 19. Yüzyllda Osmanlı Devletinde Diş̧̧ilik Mesleği (Erbâb-ı Esnân) 
Tanzimat Döneminde İsyancı Bir Ayan Profili: Acaralı Kör Hüseyin Bey Hadisesi

2. Konu-tanım:

Mebusân-ı Kirâmın Terceme-i Hâl ve Sergüzeştleri: Meşrutiyet Devrinden Unutulmuş Bir Biyografi Risalesi

3. Tespit-konu

Bulgaristan Yol Ayrımında: İvan S. Geşov Meselesi

4. Konu-metot+kapsam

Türkiye'de Harf Devriminin Belgelerin Form Yapısına Etkisi: Diplomatik Metodoloji Işığında Arşiv Belgelerinin İç Kaynaklı Elemanları Üzerine Bir İnceleme

5. Tanım-isim:

Erken Ortaçağların Şehirler Topluluğu: Medâ'in

6. Metafor-İsim:

Osmanlı Hasbahçelerinin Sultanı: Sultaniye Hasbahçesi

7. İsim-konu:

Etelköz: Ortanca Macar Yurdu Hakkında Yeni Bazı Tespitler

8. Konu-örneklem

XVI. Yüzyıl Anadolu'sunda Orman Tahribi: Hüdavendigar (Bursa) Sancağl Örneği

Kültürel Temizlik ve Bütünleşme Politikalarında Tarihin Rolü: Bosna Örneği

9. Konu-Soru

Bir Ortaçă̆ Anadolu Sûfisi Hakkında Yeni Bulgular: Aybek Baba Şeyh mi, Emir mi?

10. Tez-Konu

Düşmânlarımıza Bâ'is-i Helecân Vermek: Edirne Yeni Saray’ı Tamir Etmek 
Derlemde aynı başlıkta iki kez iki nokta işaretine yer verilen örnekler de bulunmaktadır. Bu tutum Batı literatüründe tespit edilmemiştir. Aşağıda bu tarz kullanımlar anlam incelemeleriyle birlikte örneklendirilmiştir:

11. Konu - Konu - Tarih

Türkistan'ın Erken Dönem Muhaceret Mücadelesi ve Türkistancllik: Muhacerette Milli Kimlik Tasavvuru: 1925-1940

12. Konu - Kapsam - Konu

Mir'âtü'l-Ebdân fì Teşrîh-i A 'zâi'l-İnsân'da Yer Alan Anatomi Terimleri Üzerine Bir Ön Çalışma: "Birinci Kısım: Osteoloji Hakkın$d a "$

\subsection{Soru}

Her ne kadar dünyada başlıklarda soru işareti kullanımı yaygınlaşsa da incelememizde soru işaretinin kullanım oranının 1937' den günümüze \%1'i geçmediği görülmüştür. Derlemde tespit edilen 8 örnek şu şekilde gruplandırılabilir:

$m i$

İslam Dünyasının Inhitatı Sebebi Selçuk İstilâsı mıdır?

$m i+m i$

Bir Ortaçă̆ Anadolu Sûfisi Hakkında Yeni Bulgular: Aybek Baba Şeyh mi, Emir mi?

ne

Hazine-i Bîrun Kâtibi Ahmet bin Mahmud Efendi'nin tuttuğu Prut Seferine Ait Defterden Kopartlan Sahifelerde Neler Vardt?

nerede

Osmanlı Devletine İltica Etmiş Olan Kâryeka Hânedanından Ahmed Han Nerede Vefat Etti?

neden

Fatih Sultan Mehmed'in Vezir-i Âzamlarından Mahmud Paşa İle Şehzade Mustafa'nın Araları Neden Açılmıştı? 
Tek bir örnekte soru işareti parantez içinde kullanılarak başlıkta verilen bilginin kesin olmadığı vurgulanmıştır:

Tigunānu'dan (?) Arpa Hisseleri Hakkında Bir Tablet

\section{8. Ĕ̈̆ik çizgi}

Bu noktalama işareti sadece 1985-1990 ve 2011-2016 aralıklarında ikişer kez olmak üzere toplam 4 kez kullanılmıştır. İlk üçünde verilen Hicri tarih ve Miladî tarih denkliklerini ayırmak için kullanılmıştır:

Yirmi Sekiz Mehmet Çelebi Efendi'nin Fransa Sefaretnamesi (1132-33 H./1720-21 M.)

1274/1858 Tarihli Osmanlı Ceza Kanunnamesinin Hukuki Kaynaklarl, Tatbik Şekli ve Men-i Irtikab Kanunnamesi

Osmanlı Devleti'nde Tekâlif-i İmdâdiye Vergisine Illginç Bir Örnek: H. 1044/M.1634 Yılında Uygulanan Bedel-i Yapağı Vergisi

Son örnekte ise makalede incelendiği belirtilen iki kelimeyi birbirinden ayırmak için kullanılmıştır:

Hititçe Metinlerde Geçen KUR Hulana-/ KUR SIG 'Yün Nehri Ülkesi' Üzerine Yeni Bir Değerlendirme

\subsection{Eşitlik}

Sayısal bir sembol olan eşitlik işareti sadece 1985-1990 alt derleminde 1 kez tespit edilmiştir. Bu başlıkta eşitlik işareti verilen Miladî tarih ve Hicri tarih denkliklerini göstermek için kullanılmıştır:

Kanuni Sultan Süleyman'ın Boğdan Seferi ve Zaferi (1538 $M .=945 \mathrm{H}$.)

\subsection{Tirnak}

Başlıklarda tırnak kullanımına sadece 2011-2016 aralığında 2 kez vurgu yapmak amacıyla başvurulmuştur.

Mir'âtü'l-Ebdân fî Teşrîh-i A 'zâi'l-İnsân'da Yer Alan Anatomi Terimleri Üzerine Bir Ön Çalışma: "Birinci Klsım: Osteoloji Hakkında" 
Osmanlı Algisinda Garb Teknolojisi: "Mösyö Elektrik"in Sergüzeşti

\subsection{Tek tornak}

Tek tırnak işaretine sadece 2011-2016 tarihlerinde 1 kez başlıkta verilen makalenin inceleme konusunu teşkil eden yabancı kelimelerin anlamını belirtmek amacıyla başvurulmuştur:

Hititçe Metinlerde Geçen KUR Hulana-/ KUR SIG 'Yün Nehri Ülkesi' Üzerin e Yeni Bir Değerlendirme

\section{Sonuç}

Sosyal bilimler alanında yazılmış Türkçe başlık adlarının incelenmesi amaçlanan bu çalışmada 2016-2011 yılları arasında yayınlanan 298 akademik başlıktan oluşturulan bir derlem kullanılmıştır. Başlıklar; (i) uzunluk, (ii) metin düzenlemesi, (iii) tür ve (iv) noktalama kullanımları olmak üzere dört ayrı açıdan incelenmiştir.

İnceleme sonucunda Batı dillerindeki makale başlıklarının incelenmesiyle ortaya konulan bulgulara paralel olarak:

(i) Başlık uzunluklarının ortalama 9 kelime olduğu;

(ii) Metin düzenlemelerinde en sık iki bilgi birimli başlıklara yer verildiği;

(iii) Bilgi birim sayısı ile başlıkta kullanılan kelime sayısı arasında olumlu bir ilişkinin var olduğu;

(iv) Başlıkta yer alan bilgi birimi sayısı ile makalenin boyutu arasında olumlu bir ilişki bulunduğu ortaya koyulmuştur.

Batı dillerindeki makale başlıklarının incelenmesiyle ortaya konulan bulgulardan farklı olarak:

(i) Başlıkta kullanılan kelime sayısı ile makalenin hacmi arasında anlamlı bir ilişki bulunmadığı;

(ii) Tasvirî başlıkların \%90 kullanım oranıyla Türk akademisinde en çok kullanılan başlık türü olduğu,

(iii) Batı dillerinde yaygın olarak kullanılan bildirim başlıklarının kullanım oranının Türkçe makalelerde ancak \%7 olduğu; 
(iv) Araştırma sorusunun bütün yönlerini içine alan bildirim başlığının bulunmadığı, bu tip başlıkların araştırma makalesinin sonucunun/tezinin genelleştirilmesiyle oluşturulduğu;

(v) Her ne kadar Batı literatüründe soru başlıklarında var olan bir artıştan söz edilse de incelememizde bu tür başlıkların kullanım oranının sadece $\% 2$ olduğu;

(vi) Her 100 akademik başlıktan 74'ünde noktalama işaretlerine yer verildiği,

(vii) Makale başl1klarında toplam 10 noktalama işareti türünün kullanıldığ1,

(viii) En sık kullanılan noktalama işaretinin ise kesme işareti olduğu belirlenmiştir. 


\section{Kaynaklar}

Anthony, L., (2001) "Characteristic Features of Research Article Titles in Computer Science", IEEE Transactions on Professional Communication, 44 (3), s. 187-194.

Ball, R., (2009) "Scholarly communication in transition: the use of question marks in the titles of scientific articles in medicine, life sciences and physics" 1966-2005. Scientometrics, 79 (3), s.667-679.

Biacchi, A. (2003) "Relation complexity of titles and texts: A semiotic taxonomy", Editör: MERLINI BARBARESI, L., Complexity in Language and Text,. Pisa: PLUS, s.319-341.

Biswas, Asit K. ve Kirchherr, J., (2015) "Prof, no one is reading you", The Straits Times, http:// www.straitstimes.com/news/opinion/ more-opinion-stories/story/prof-no-one-readingyou-20150411, Türkçe çevirisi http://t24.com.tr/haber/profesor-hic-kimse-siziokumuyor,298153, 28.11.2016.

Busch-Lauer, I., (2000) "Titles in English and German research papers in medicine and linguistics", Analysing Professional Genres, Editör: TROSBORG, A., Amsterdam: John Benjamins, s.77-97.

Butek, RK ve van Raan AFJ., (2011) "Non-alphanumeric characters in titles of scientific publications: an analysis of their occurrence and correlation with citation impact", Journal of Informetrics, 5 (4), s. 608-617

Buxton, A. B., ve Meadows, A. J. (1977). "The variation in the information content of titles of research papers with time and discipline", Journal of Documentation, 33 (1), s.46-52.

Cheng, S.W., KUO C.W. ve KUO C.H., (2012) "Research article titles in applied linguistics" Journal of Academic Language \& Learning, 6 (1), s.1-14.

Dillon, J. T. (1981) "Functions of the Colon: An Empirical Test of Scholarly Character", Educational Research Quarterly, 5, s.7175.

Dillon, J. T. (1982) "In Pursuit of the Colon: A Century of Scholarly Progress: 1880-1980”, Journal of Higher Education, 53 (1), s.93-99. 
Forray, J. M. ve Woodilla, J. (2005) "A discourse analysis of temporality in journal titles", Time \& Society, 14 (2-3), s.323-339.

Fortanet I., Coll J. F., Palmet J. C., Posteguillo S. (1997) “The Writing of Titles in Academic Research Articles", Editör: CHAMORRO R. M., NAVARRETE A. R., Lenguas aplicadas a las ciencias y la tecnologia. Approximaciones, Caceres, Spain: Universidada de Extremadura, Servicio de Publicaciones, s.155-158.

Fortanet I., Posteguillo S., Coll J. F., Palmer J. C. (1998) "Linguistic Analysis of Research Article Titles: Disciplinary Variations", Editör: VAZQUEZ I., CAMILLEU I., Perspectivas Praguietices en Linguistica Aplicada, Zaragoza, Spain: Anubar, s.443-447.

Gesuato, S., (2008) "Encoding of information in titles: Academic practices across four genres in linguistics", Editör: TAYLOR, C., The Role of Ecorpora in Translation and Language learning, Ecolingua Italy: EdizioniUniversità di Trieste, s.127-157.

Goodman, R., Thacker, S. ve Siegel, P., (2001) "What's in a title? A descriptive study of article titles in peer reviewed medical journals", Science Editor, 24 (3), s.75-78.

Habibzadeh, F. ve Yadollahie, M., (2010) "Are shorter article titles more attractive for citations? Cross-sectional study of 22 scientific journals", Croatian Medical Journal, 51 (2), s.165-170.

Haggan, M. (2004). "Research paper titles in literature, linguistics and science: Dimensions of attractions", Journal of Pragmatics, 36, s.293-317.

Hartley J. (2007a) “'Colonic titles!', The Write Stuff”, The Journal for European Medical Writers, 16 (4), s.147-149.

Hartley J. (2007b) "There's More to the Title than Meets the Eye: Exploring the Possibilities", Journal of Technical Writing and Communication, 37, s.95-101.

Jacques, TS ve Sebire, NJ., (2009) "The impact of article titles on citation hits: an analysis of general and specialist medical journals", Journal of the Royal Society of Medicine Short Reports, 1 (2), s.1-5.

Jamali, H.R. ve Nikzad, M., (2011) "Article title type and its relation with the number of downloads and citations", Scientometrics, 88 (2), s.653-661. 
Lewinson, G. ve J. Hartley, (2005) "What's in a Title? Number of Words and the Presence of Colons", Scientometrics, 63 (2), s.341-356.

Michelson G. (1994) "Use of Colons in Titles and Journal Status in Industrial Relations Journals", Psychological Reports, 74, s.657-658.

Moore, A., (2010) Do Article Title Attributes Influence Citations?, New York: Wiley-Blackwell Publishing News.

Nord C. (1995) "Text-Functions in Translation: Titles and Headings as a Case in Point", Target, 7 (2), s.261-284.

Rosner, JL., (1990) "Reflections of science as a product", Nature, 345: s. 108.

Sagi, I ve Yechiam, E., (2008) "Amusing titles in scientific journals and article citation", Journal of Information Science, 34 (5), s.680-687.

Salager-Meyer, F. ve Alcaraz Ariza, M. Á. (2013). "Titles are "serious stuff": A historical study of academic titles", Jahr, 4 (7), s.257-271.

Soler, V. (2011) "Comparative and contrastive observations on scientific titles in written English and Spanish", English for Specific Purposes, 30, s.124-137.

Stremersch, S, Verniers, I ve VERHOEF, P. C., (2007) "The quest for citations: drivers of article impact", Journal of Marketing, 71 (3), s.171-193.

Wang, Y., \& Bai, Y. (2007). "A corpus-based syntactic study of medical research article titles", System, 35, s.388-399.

Whissell, C. (1999). Linguistic complexity of abstracts and titles in highly cited journals, Perceptual and Motor Skills, 88, s.76-86.

Yitchaki, M,. (1994) "Relation of the title length of journal articles to number of authors", Scientometrics, 30 (1): s.321-332. 